\title{
An Examination of Elementary School Students' Parental Style and Parental Internet Style with Respect to Various Variables
}

Metin DENiZ, Yrd. Doç. Dr., Bartın Üniversitesi, Eğitim Fakültesi, metindeniz19@gmail.com M. Barış HORZUM, Doç. Dr., Sakaraya Üniversitesi, Eğitim Fakültesi, mhorzum@sakarya.edu.tr Tuncay AYAS, Doç. Dr., Sakaraya Üniversitesi, Eğitim Fakültesi, tayas@sakarya.edu.tr Mustafa KOÇ, Doç. Dr., Sakaraya Üniversitesi, Eğitim Fakültesi, mkoc@sakarya.edu.tr

\begin{abstract}
The aim of this study is to determine the relationship between parental style and internet parental style and find out whether student's parental style and parental internet style differ according to various variables. In this study, survey model was used. The study was performed with 296 students, attending at an elementary school in the second period of 2011-2012 academic years in Sakarya, Turkey. Parental style and parental internet style scales were used. Results indicated that there is a significant relationship between students' parental style and their family's parental internet style. It was also found that students' gender is a significant variable in their parental style and parental internet style. Moreover, it was determined that there is a significant relationship between students' family's parental internet style and their grade at school.
\end{abstract}

Key Words: Parental style, Parental internet style, Gender, Grade, Internet use.

\section{Illköğretim Öğrencilerinin Aile Tutumu ve İnternet Aile Tutumunun Çeşitli Değişkenler Açısından İncelenmesi}

Öz: Araştırmanın amacı ilköğretim öğrencilerinin anne baba tutumu ve ailelerinin internet tutumunu belirlemek ve öğrencilerin aile internet tutumu ve anne baba tutumunun çeşitli değişkenlere göre farklılaşıp farklılaşmadığını incelemektir. Araştırmada genel tarama modelindedir. Araştırma 20112012 öğretim yılının ikinci döneminde, Sakarya îli Merkezinde yer alan bir ilköğretim okulunda ikinci kademede öğrenim gören toplam 296 öğrenci ile gerçekleştirilmiştir. Araştırmada aile tutumu ve internet aile tutumu ölçekleri kullanılmıştır. Araştırma sonuncunda öğrencilerin anne baba tutumu ile ailelerinin internet tutumları arasında anlamlı ilişki olduğu ortaya çıkmıştır. Ayrıca anne baba tutumları ve aile internet tutumlarında öğrencilerin cinsiyetlerinin anlamlı bir değişken olduğu bulunmuştur. Bunun yanında öğrencilerin ailelerinin internet tutumları ile öğrenim gördükleri sınıfları arasında anlamlı ilişki olduğu da bulunmuştur.

Anahtar Kelimeler: Ana baba üslubu, Internet ana baba üslubu, Cinsiyet, Sınıf, İnternet kullanımı. 


\section{INTRODUCTION}

All kinds of attitude shown towards the children by parents will form the basis for the behavior of children in the coming period will show. With the widespread usage of internet in parallel with the technological developments, family members show different attitudes towards internet that is used by their children more widely and also exhibit different approaches depending on the children's online behavior.

Internet access at home was not a common practice in the periods when internet first started to be used. Internet was widely used at internet cafes or government agencies generally. The fact that especially teenagers was using internet at internet cafes presented an obstruction for that some parents would not have enough information on to what end and how long their children used internet. This situation was likely to differentiate families' parental internet style.

Internet have today been accessed everywhere. Use of internet at home has become widespread. Internet now is even more accessible thanks to smart phones. In parallel with these advancements, one can see that there have been changes in styles of families towards the use of internet of their children. Different styles of families towards internet use of their children may affect the behaviors of the children about using internet.

The fact that excessive misuse of the internet by individuals affect their biological, academic, physiological, psychological and social development negatively (Anderson \& Bushman, 2001; Caplan, 2002; Yang, Choe, Baity, Lee \& Cho, 2005). Families will also differentiate their own attitudes, based on their awareness about these negative effects of internet. In a study, it was found that families of internet-addicted students did not actually care about them enough (Huang et al., 2009). In the study by Ko, Yen, Yen, Chen, Weng and Chen (2008) it was found that there is a relationship between problematic use of internet and high conflict level between parents-teenagers, high conflict between parents and low level of family functions. Children who cannot receive the necessary support from their families and have problems with them use the virtual world as an escape to overcome the problem they experience (Lim, Bae \& Kim, 2004). Since students who have emotional and behavioral problems in their daily lives are criticized by their parents and teachers due to their problems more often, they may be using internet as an alternative to let their anger to empty and satisfy the feeling of success (Cao \& Su, 2006). Kıran Esen and Gündoğdu (2010) found that there is a negative relationship between the problematic use of internet and parental/teacher support.

When family members do not act supportive for each other, child seeks for the help in different channels. The most important one of these channels were found to be internet (Moazedian et al. 2014). Lin, Lin and Wu (2009) stated that use of internet is negatively affected by being subject to control of family and doing outdoor activities with family. In a study carried out by Jeong and Hwan Kim (2011) on high school student, they found a negative relationship between participating in social activities with family and problematic use of internet. Young (2004) stated that factors, which cause misuse of internet by teenagers, include the fact that family members cannot control their internet access enough or nothing obstructs their use of internet. On the other hand, Giles and Price (2008) stated that in a family setting where children's behavior are very closely followed, they are overprotected and not allowed to be autonomous and this process may establish an environment for problematic use of internet depending on the increase of parent-child conflict.

Since most of the families think that internet would contribute to their children's educational life and affect their children's academic achievements positively, they believe that internet should be widely used (Yen, 2002; Jones, 2006). Aksüt, Özer, Gündüz and KaşıkcI 
(2008) determined that parents do not exhibit a hindering attitude towards use of internet by children of elementary school students. However, it is seen that conflicts are often at home when internet isn't used for educational purposes (Mesch, 2003).

Moazedian et al. (2014) stated that children of indulgent and negligent parental styles are addicted to internet less than those of authoritarian parental style. It was determined in the same study that children who have a warmly family atmosphere are addicted to internet less. Çevik and Çelikkaleli (2010) found that problematic internet use level of children of families with negligent parental style is higher than the children of families with indulgent, authoritative and authoritarian parental style. Valcke, Bonte, De Wever and Rots (2010) also stated that internet use of the children of families with indulgent style is high while internet use of the children of families with authoritative parental style is low.

Hsu (2005) stated that children of families with negligent are more of problematic internet users. Ayas and Horzum (2013) determined that the children of the families with a negligent style towards internet use were found to be more addicted than those of the families with authoritarian, indulgent and authoritative internet parental style. In the study by Xiuqin et al. (2010) it was found that internet-addicted teenagers' parents have low level of emotional warmth, are highly rejectionist and mother is highly punisher. In a study by Horzum and Bektaş (2014) it was revealed that authoritative internet style of families have an important role in use of internet for different purposes.

When the literature is examined, it is seen that different parental styles are effective in behaviors of children's use of internet. It is also seen that there is limited research on families' parental styles and parental internet styles whether similar or different. The aim of this study is to examine whether there is a relationship between parental attitudes and parental internet style of elementary school students and to examine parental internet style depending on several variables.

\section{METHOD}

\subsection{Participants}

This study was carried out using survey model. The population of this study consists of totally 269 students, 121 (45\%) of which are female and 148 (55\%) of which are male, attending at an elementary school in the second period of 2014-2015 academic years in Sakarya, Turkey. $109(40.5 \%)$ students study at sixth grade, $94(34.9 \%)$ at seventh grade and 66 $(24.5 \%)$ at eighth grade. 174 (64.7\%) of mothers of the students are primary school graduates, $54(20.1 \%)$ of them are secondary school graduates, $35(13 \%)$ of them are high school graduates and $6(2.2 \%)$ of them are university graduates. $139(51.7 \%)$ of fathers of the students are primary school graduates, $61(22.7 \%)$ of them are secondary school graduates, 53 $(19.7 \%)$ of them are high school graduate and 16 (5.9\%) of them are university graduates. 205 (76.2\%) of the students stated that they had personal computer and 164 (23.8\%) of them stated they had no personal computer. $171(63.6 \%)$ of the students stated that they had internet connection at home and $98(36.4 \%)$ of them stated they had no internet connection at home. 28 (10.4\%) of the students stated that they got help from their mother, 97 (36.1\%) from their father and 144 (53.5\%) from no one. 144 (53.5\%) of the students stated that they were warned by their mothers in case they used internet too long, $96(35.7 \%)$ by their fathers and $29(10.8 \%)$ by no one. 


\subsection{Instruments}

In this study, parental style and parental internet style scales were used.

Parental Style Scale: The scale developed by Lamborn, Mounts, Steinberg and Dornbush (1991) and adapted by Yılmaz (2000). The original scale includes 3 factors: involvement, supervision and psychological autonomy. Involvement and supervision subdimensions were used in this study. Cronbach's Alpha internal consistency coefficient is .72, for involvement sub scale and .82 for supervision sub scale. Four parental styles is available from the intersection of involvement and control factors.

The participants' parents who scored above the median are defined as Authoritative; those who scored below it are defined as negligent for involvement and supervision factors; those who scored below for involvement factor and above for supervision factor are defined as authoritarian; those who scored above for involvement factor and below for supervision factor are defined as indulgent (Yılmaz, 2000). In this study, internet parental style numbers for these four styles are given in Figure 1.

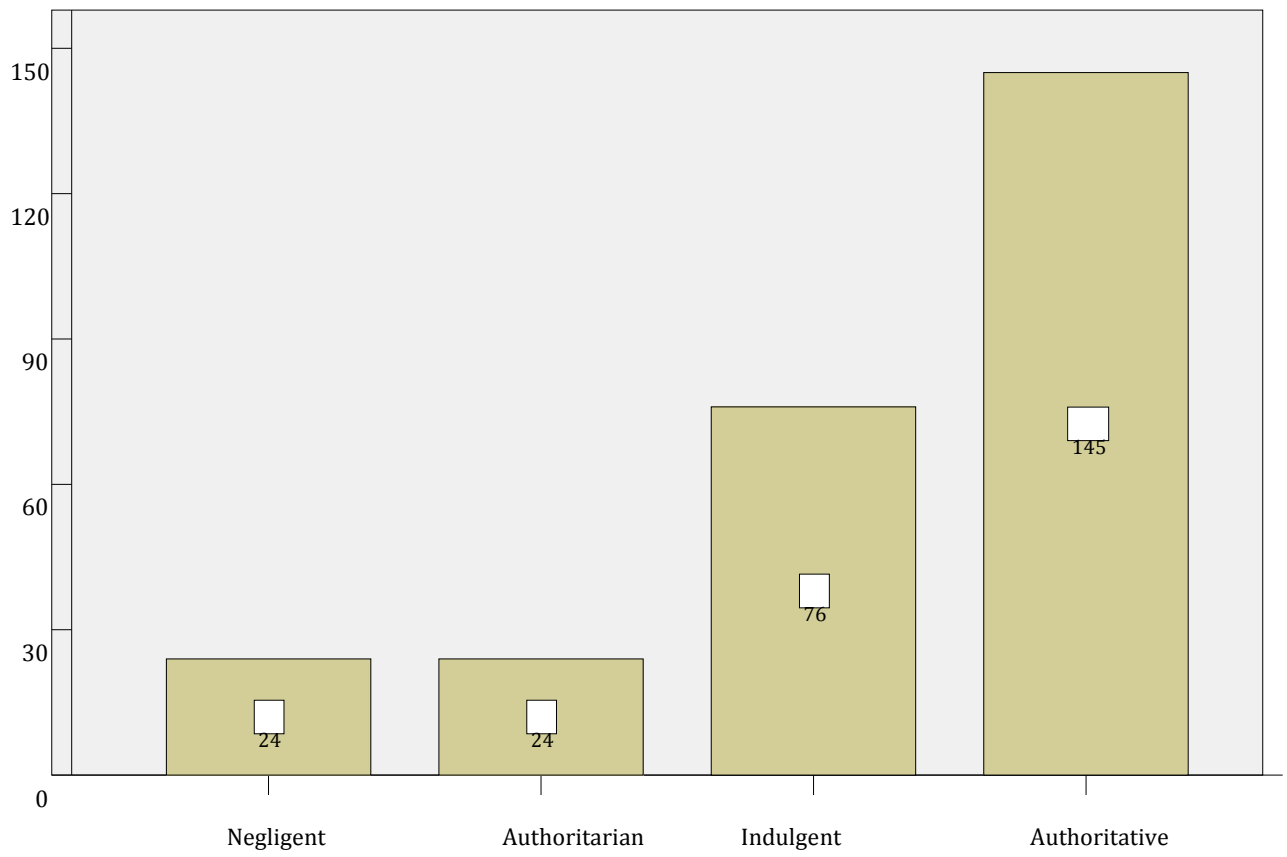

Figure 1. Parental style distribution of study group

Parental Internet Style Scale: The scale was developed by van Rooij and van den Eijden (2007). The original of the scale is in Dutch. The scale was translated into English by Valcke, Bonte, De Wever and Rots (2010) and was adapted into Turkish by Ayas and Horzum (2013). The scale consists of two factors including 25 items. "Parental control" factor consists of 11 items and "Parental Warmth" factor consists of 14 items. Confirmatory factor analysis results as follow; $\chi 2=485.76(\mathrm{sd}=253, \mathrm{p} .=.00), \chi 2 / \mathrm{sd}=1.92 \mathrm{RMSEA}=0.048, \mathrm{GFI}=0.91, \mathrm{AGFI}=$ $0.89, \mathrm{CFI}=0.99, \mathrm{NFI}=0.97$ and $\mathrm{NNFI}=0.98$. Cronbach's Alpha internal consistency coefficient was found as .94 for the total of the adapted 25-item scale. Cronbach's alpha internal consistency coefficient was found .86 for "Parental control" factor and .92 for "Parental Warmth" factor. 
It is possible to use the scale in two ways. In the first one, total score is obtained for parental control and warmth dimensions in the scale. Second use is the way which is recommended in the original of the scale and which is used in this study. In this use, a score between 1 and 5 is obtained from the items included in dimensions of parental control and warmth for each participant. For these scores, those under 3 are considered as low and others are considered as high. In other words, there is a $2 \times 2$ structure consisting of low/high control and low/high warmth. Negligent, authoritarian, indulgent and authoritative parental styles are formed in the scale. In this study, parental internet style numbers for these four attitudes are given in Figure 2.

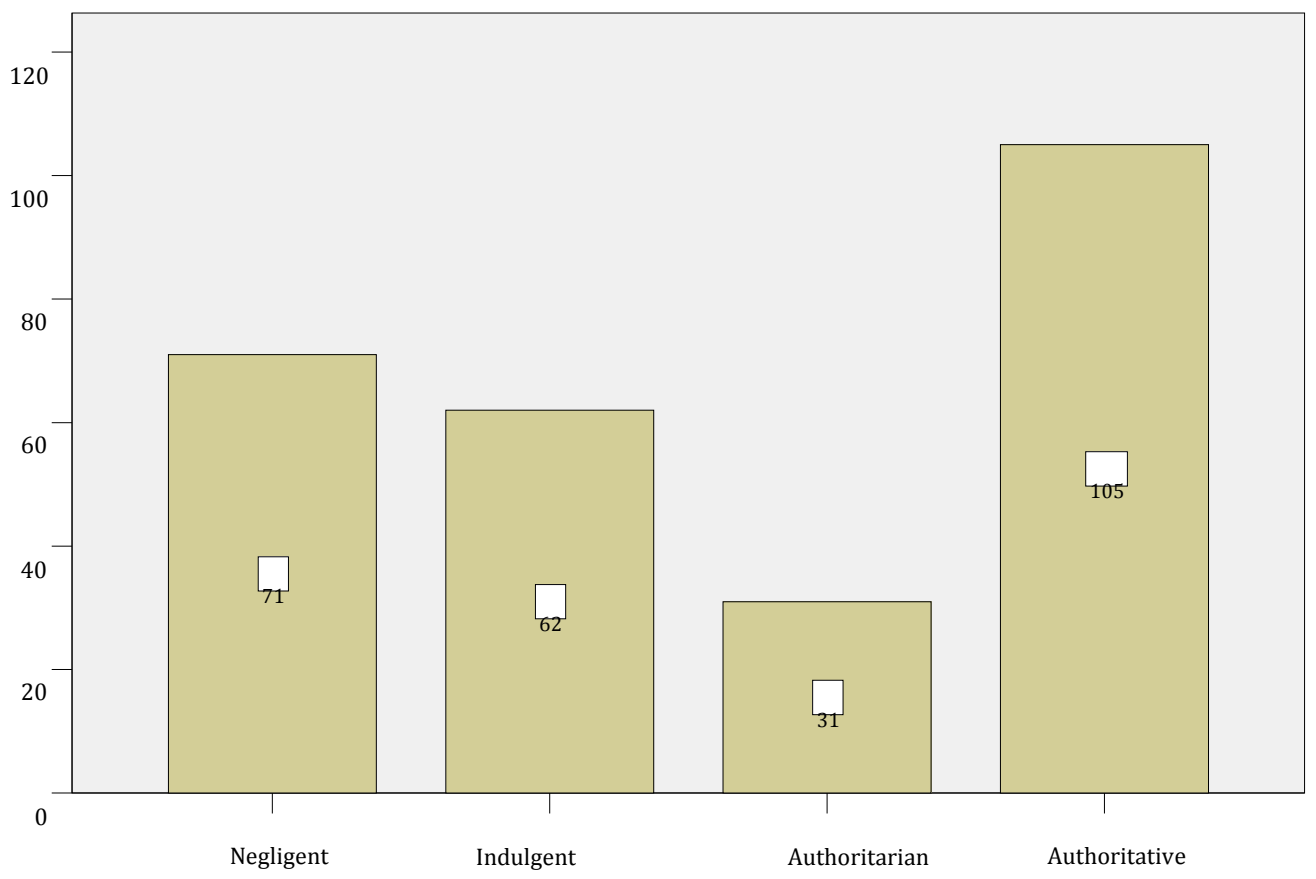

Figure 2. Parental internet style distribution of study group

\subsection{Analysis of Data}

Data collection instrument was applied to the students participating in the study by being delivered by hand. Data collected in the study was entered into SPSS 13.0 package program and statistical processes were made. In the research, the relation between family internet attitudes and other variables were examined with Chi-square test. 


\section{RESULTS}

Two-variable Chi-square analysis was performed to find whether there is a relationship between parental style and parental internet style in this study. Data obtained as a result of the analysis are given in Table 1.

Table 1

Chi-Square Table for the Relationship between Parental Style and Parental Internet style

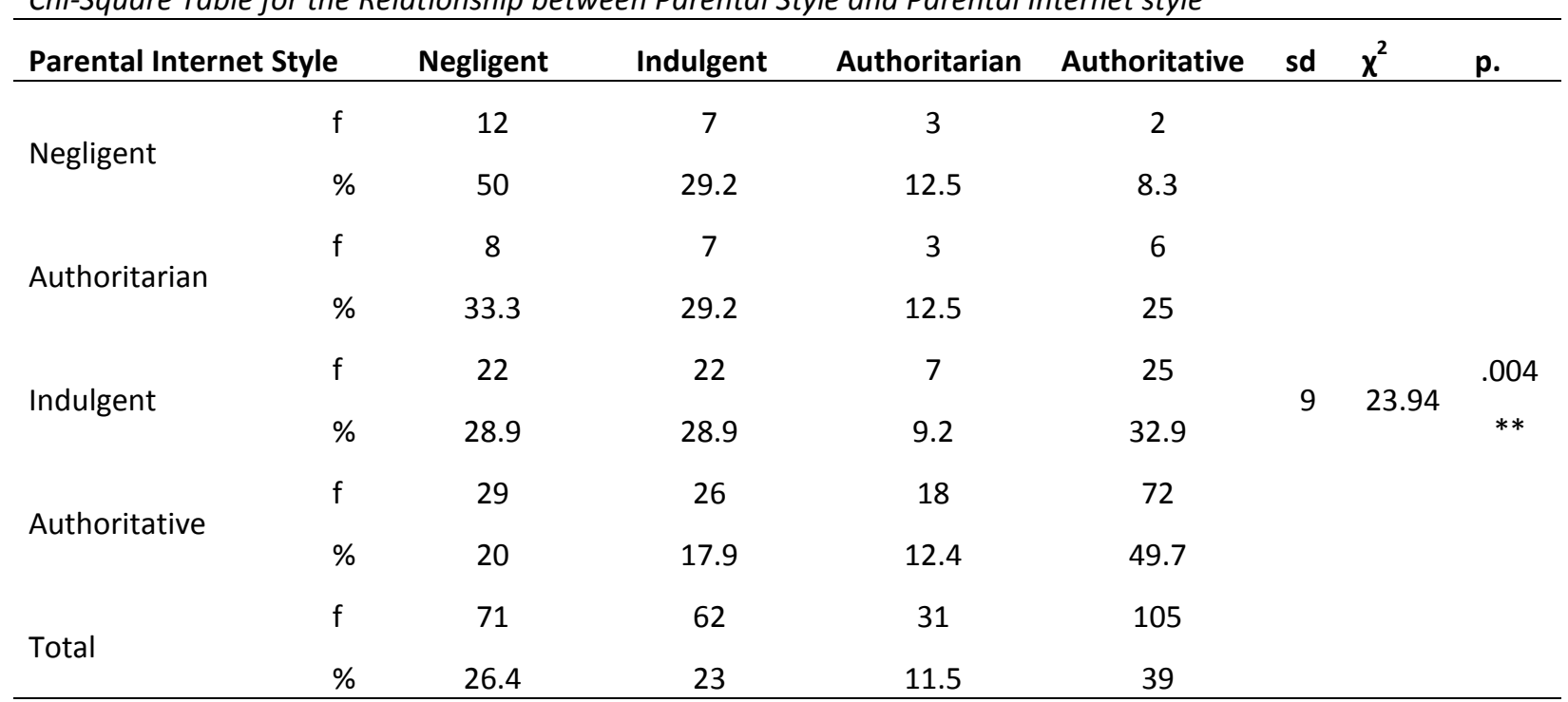

When Table 1 is analyzed, based on the students' families' parental styles whose parental styles are negligent, $12(50 \%)$ have negligent internet parental style, 7 (29.2\%) have indulgent internet parental style, $3(12.5 \%)$ have authoritarian internet parental style and 2 (8.3\%) have internet authoritative parental style. Based on the family style of students whose parental style is authoritarian, $8(33.3 \%)$ have negligent internet parental style, 7 (29.2\%) have indulgent internet parental style, $3(12.5 \%)$ have authoritarian internet parental style and 6 $(25 \%)$ have authoritative internet parental style. Based on the family style of students whose parental style is indulgent, 22 (28.9\%) have negligent internet parental style, $22(28.9 \%)$ have indulgent internet parental style, $7(9.2 \%)$ have authoritarian internet parental style and 25 (32.9\%) have authoritative internet parental style. Moreover, based on the family style of students whose parental style is authoritative $29(20 \%)$ have negligent internet parental style, $26(17.9 \%)$ have indulgent internet parental style, 18 (12.4\%) have authoritarian internet parental style and $72(49.7 \%)$ have authoritative internet parental style. It was found that there is a significant relationship $(\chi 2(9)=23.94, p<.05)$ between students' parental style and their families' parental internet style. These findings indicate that parental styles are a significant variable to internet parental style of families of elementary school second stage students.

It was analyzed with two-variable Chi-square test whether there is a relationship between students' parental style and variables such as their gender, grade, educational background of parents, availability of computer and internet connection at home, internet using levels of parents, from whom they get help when they have problem with internet and by whom they are warned when they have used internet excessively. Chi-square table for whether there is a relationship between parental style and students' gender is given in Table 2 . 
Table 2

Chi-Square Table of the Relationship between Parental Style and Students' Gender

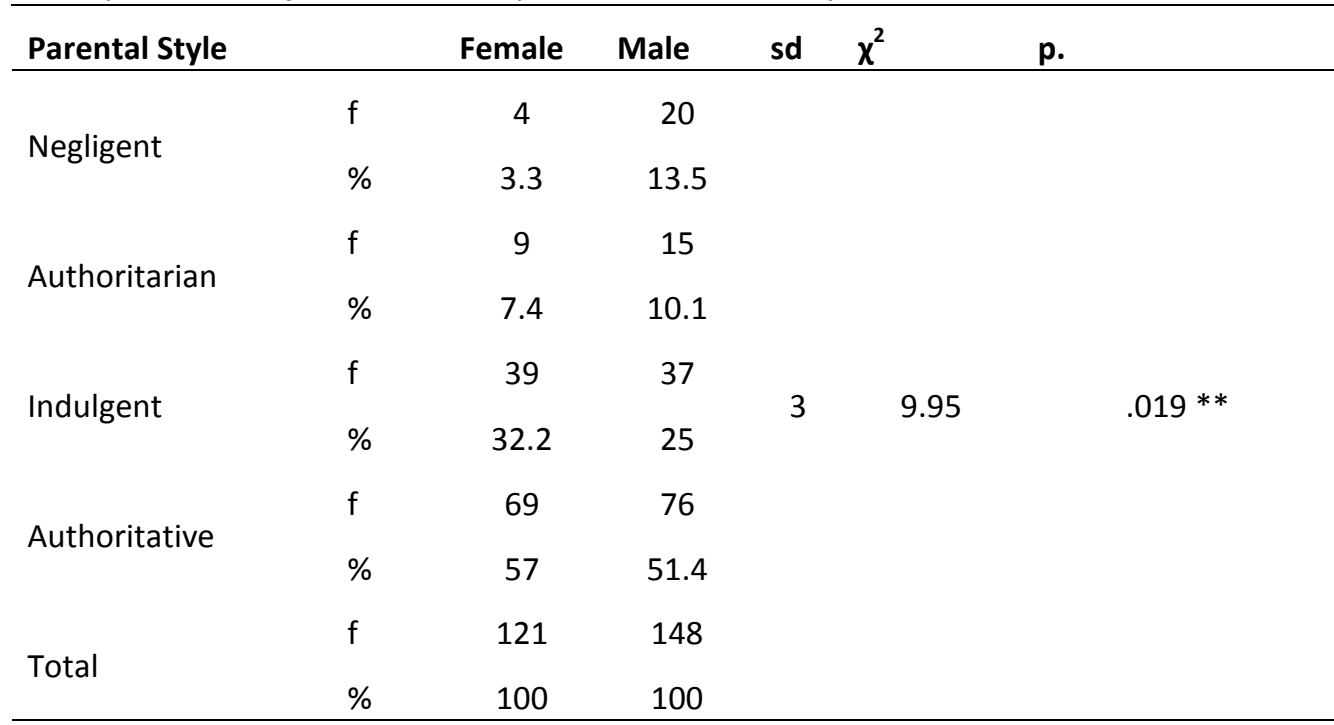

When Table 2 is analyzed, for parental style, 4 (3.3\%) female students' families have negligent parental style, 9 (7.4\%) have authoritarian parental style, 39 (32.2\%) have indulgent parental style and 69 (57\%) have authoritative parental style. Moreover, for parental style, 20 (13.5\%) male students' families have negligent parental style, 15 (10.1\%) have authoritarian parental style, $37(25 \%)$ have indulgent parental style and $76(51.4 \%)$ have authoritative parental style. It was found that there is a significant relationship $(\chi 2(3)=9.95, p<.05)$ between students' families' parental style and their gender. This finding indicates that gender of students is a significant variable in parental style.

In addition, no relationship was found between parental style and variables such as their grade, number of brothers and sisters, internet using skill, educational background of parents, availability of internet connection at home, from whom the student gets help in case of a problem and by whom the student is warned in case of long duration of internet use. The Chi-square table was not included in the article since there was no significant relationship in those findings.

It was analyzed with Chi-square test whether there is a relationship between parental internet style and variables such as their gender, grade, number of brothers and sisters, educational background of parents, availability of computer and internet connection at home, internet using levels of parents, from whom they get help when they have problem with internet and by whom they are warned when they have used internet excessively. Chi-square table for whether there is a relationship between parental internet style and students' gender is given in Table 3. 
Table 3

Chi-Square Table of the Relationship between Parental Internet Style and Students' Gender

\begin{tabular}{lcccccc}
\hline Parental Internet Style & Female & Male & sd & $\chi^{2}$ & p. \\
\hline \multirow{2}{*}{ Negligent } & $\mathrm{f}$ & 15 & 56 & & & \\
& $\%$ & 12.4 & 37.8 & & & \\
Indulgent & $\mathrm{f}$ & 35 & 27 & & & \\
& $\%$ & 28.9 & 18.2 & & & \\
Authoritarian & $\mathrm{f}$ & 16 & 15 & & & \\
& $\%$ & 13.2 & 10.1 & 3 & 22.50 & \\
Authoritative & $\mathrm{f}$ & 55 & 50 & & & \\
& $\%$ & 45.5 & 33.8 & & & \\
Total & f & 121 & 148 & & & \\
& $\%$ & 100 & 100 & & & \\
\hline
\end{tabular}

When Table 3 is analyzed, 15 (12.4\%) of families with female students have negligent parental style, 35 (28.9\%) have authoritarian parental style, 16 (13.2\%) have indulgent parental style and 55 (45.5\%) have authoritative parental style. Moreover, 56 (37.8\%) of families with male students have negligent parental style, 27 (18.2\%) have authoritarian parental style, 15 (10.1\%) have indulgent parental style and 50 (33.8\%) have authoritative parental style. It was found that there is a significant relationship between parental internet styles of students' families and their genders $(\chi 2(3)=22.50, p<.05)$. This finding indicates that gender of students is a significant variable in parental internet styles of families. Chi-square table for whether there is a relationship between parental internet style and students' grades is given in Table 4.

Table 4.

Chi-Square Table of the Relationship between Parental Internet Style and Students' Grades

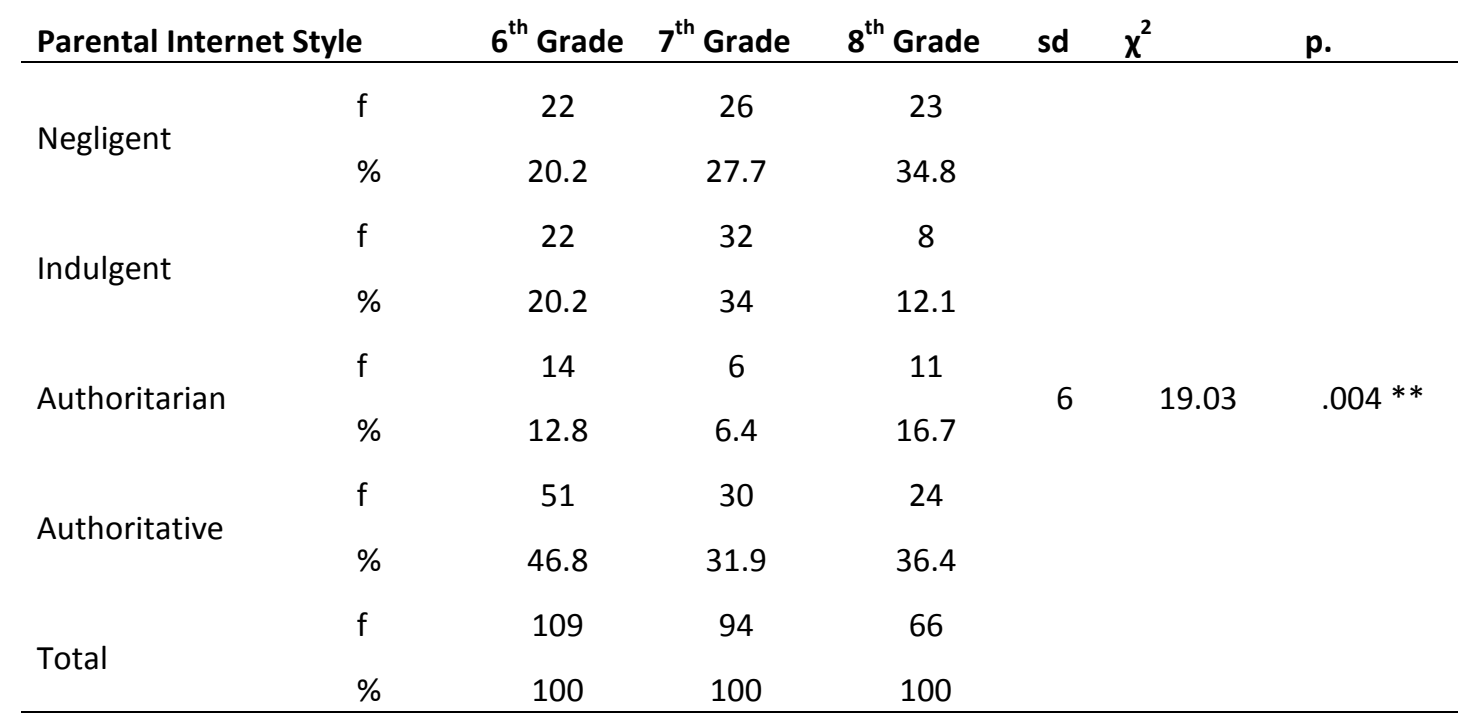

When Table 4 is analyzed, 22 (20.2\%) of families with 6th grade students have negligent parental style, $22(20.2 \%)$ have authoritarian parental style, 14 (12.8\%) have indulgent parental style and 51 (46.8\%) have authoritative parental style towards internet usage. $26(27.7 \%)$ of families of 7 th grade students have negligent parental style, 32 (34\%) 
authoritarian parental style, $6(6.4 \%)$ have indulgent parental style and 30 (31.9\%) have authoritative parental style towards internet usage. In addition, 23 (34.8\%) of families of 8th grade students have negligent parental style, $8(12.1 \%)$ authoritarian parental style, $11(16.7 \%)$ have indulgent parental style and $24(36.4 \%)$ have authoritative parental style towards internet usage. It was found that there is a significant relationship between parental internet styles of students' families and their grades $(\chi 2(6)=19.03, p<.05)$. This finding indicates that grade of students is a significant variable in parental internet styles of families.

In addition, no relationship was found between parental internet styles and variables such as their grade, number of brothers and sisters, internet using skill, educational background of parents, availability of internet connection at home, from whom the student gets help in case of a problem and by whom the student is warned in case of long duration of internet use. The Chi-square table was not included in the article since there was no significant relationship in those findings.

\section{DISCUSSION, CONCLUSION AND SUGGESTIONS}

Internet is one of the growths that facilitate people's lives according to the individuals' purposes of use. When children use internet especially to access information for educational purposes, they can highly benefit from internet. Beside educational purposes, appropriate use of internet also provides convenience for individuals. Misuse and excessive use of internet may affect individuals negatively.

Highly widespread of internet and its increasing popularity due to the convenience it provides for individuals, especially teenager using internet much more and surfing on internet too much requires that families control the process by monitoring their children (Wang, Bianchi \& Raley, 2005). Families' problem of not sparing time for their children due to their busy working life and the fact that they do not have the knowledge and skill as their children about technological developments presents hindrance for controlling their children about their use of internet and internet activities (van den Eijnden et al., 2010). It is important to determine how styles of families affect children's styles towards internet usage and how these styles affect children's use of internet.

In this study it was revealed that students with negligent parental style have more negligent parental styles towards internet and students with authoritarian parental style have negligent parental styles. Students' parents with indulgent parental style have primarily authoritative parental styles for parental styles towards internet. Moreover, students with authoritative parental style have more authoritative parental styles for parental styles towards internet. It is seen that parental styles have partly similar and related to their styles towards internet.

It is seen that parents with negligent-faire style have negligent styles towards internet too. Parents with negligent style are generally indifferent to their children and do not feel the urge to control them. These families provide their children with food and clothing, but they do not show emotional intimacy to their children most of the time (YIImaz, 2000). The fact that families with such style attend to their children's vital needs only makes one think that they do not attend to their other needs and is indifferent to what their children do either. When considered from this aspect, it is seen in the study that families with negligent style act negligent before their children's all behaviors and show a negligent style towards their use of internet.

Parents with an authoritarian style show a negligent style towards internet. The fact that authoritarian families who control everything under normal circumstances acts negligent- 
about internet may be stemming from either their lack of knowledge about internet or that they think internet is an important advancement that highly contributes to their children. Since some families think that internet will contribute to their children's growth, they also think their children should use the internet widely (Aksüt et al. 2008; Jones, 2006; Yen, 2002). Families with negligent and authoritative style show an authoritative style towards internet.

Although parents with indulgent style show too much tolerance to their children under normal circumstances, they may show an authoritative style towards internet since they are likely to have enough knowledge about internet. Families with authoritative style show an authoritative style towards internet too, and express their styles towards internet to their children clearly and apprehensible. Although they have an open communication with their children and support them about internet, they may be setting bounds to necessary points.

In another finding of the research, it is seen that parental styles are more authoritative for both female and male children, and a more negligent style is shown against male children while a more authoritative one is shown against female children. Various voluntary organizations such as Foundation of Mother-Child Education, press and universities have started to organize educational programs for parents, and there have been studies by school counselors so that parents can raise their children more healthily in recent years in Turkey.

It was seen that parents from all parts of the society need information on child growth and education, and parent-child communications developed positively at the end of such educational programs applied even limitedly (Şahin \& Kalburan, 2009). Such activities may have caused that parents showed an authoritative style against their children. Findings on parents' internet style partly differ from findings by Ayas and Horzum (2013). In this study performed earlier, it was determined that families' showed a negligent style against both male and female children in their styles towards internet. However, while female children were shown an authoritative style, male children were shown a negligent style in this study. The reason may be that participants in both studies were from provinces of different development levels.

Another finding of the study is that there is a significant difference between grade and families' parental style towards internet usage. This finding shows consistency with the study by Ayas and Horzum (2013). However, families with 6th grade students showed an authoritative style towards internet while they showed a negligent-faire style for 7th and 8th grade student in the study by Ayas and Horzum (2013) as in this study, it is seen that they showed an authoritative style towards internet for 6 th, 7 th, and 8 th grade students.

The fact that families do not have enough knowledge on internet may cause that they showed different styles towards internet for their children. However, while the fact that studies on internet and internet addiction have remained on agenda widely in recent times, and that researches have been performed on that negative styles towards children by their families direct the children towards internet more while their positive styles protect them from negative effects of internet may have caused them to show an authoritative style against their children. In parallel with this, the fact that families did not have the same level of knowledge on internet in previous years as today may have been effective in families showing a negligent style towards internet for their children.

Internet has been occupying every area of our lives so much that parents have started to use internet for long periods and increased their knowledge and skills on internet. In families who have the necessary knowledge on internet, they may have started to show a more positive style towards internet for their children. In future studies, it can be examined whether families of different socio-economic levels have both different parental styles and 
family internet. And the children reported both styles of families in these studies. For further studies, comparisons can be made between families' own reports and children's report.

\section{REFERENCES}

Aksüt, M.; Özer, I.; Gündüz, A. \& Kaşıkcı, P. (2008, Şubat). illköğretim öğrencilerinin internetten yararlanmalarına ilişkin Anne-Baba tutumlarının değerlendirilmesi. Akademik Bilişim konferansı, Çanakkale Onsekiz Mart Üniversitesi, Çanakkale, 30 Ocak - 01 Şubat 2008. pp: 475-479.

Anderson, C. A. \& Bushman, B. J. (2001). Effects of violent video games on aggressive behaviour, aggressive cognition, aggressive affect, physiological arousal, and prosocial behaviour: A meta-analysis of the scientific literature. Psychosocial Science, 12, 353-359.

Ayas, T. \& Horzum, M. B. (2013). İlköğretim öğrencilerinin internet bağımlılığı ve aile internet tutumu. Türk Psikolojik Danışma ve Rehberlik Dergisi 39, 46-57

Cao, F. \& Su, L. (2006). Internet addiction among Chinese adolescents: Prevalence and psychological features. Child: Care, Health and Development, 33(3), 275-281.

Caplan, S. E. (2002). Problematic Internet use and psychosocial well-being: Development of a theory- based cognitive-behavioral measurement instrument. Computers in Human Behavior, 18, 553-575.

Çevik, B. G. \& Çelikkaleli, Ö. (2010) Ergenlerin arkadaş bağlılığı ve internet bağımlılığının cinsiyet, ebeveyn tutumu ve anne baba eğitim düzeylerine göre incelenmesi. Ç.Ü. Sosyal Bilimler Enstitüsü Dergisi, 19(3), 225-240.

Giles, G. \& Price, I. R. (2008). Adolescent computer use: Approach, avoidance, and parental control. Australian Journal of Psychology, 60(2), 63-71.

Horzum, M. B. \& Bektaş, M. (2014). Examining the internet use aim and internet parental style of primary school students in terms of various variables. Croatian Journal of Education, 16(3).

Hsu, Y. H. (2005). A Study on the network usage and network literacy of fifth and sixth graders in remote areas of Taipei country. Unpublished master's thesis, National Taipei University of Education, Taipei, Taiwan.

Huang, R. L., Lu, Z., Liu, J. J., You, Y. M., Pan, Z. Q., Wei, Z., He, Q. \& Wang, Z. Z. (2009). Features and predictors of problematic internet use in Chinese college students. Behaviour \& Information Technology, 28(5), 485-490.

Jeong, E. J. \& Hwan Kim, D. (2011). Social activities, self-efficacy, game attitudes, and game addiction. Cyberpsychology, Behavior, and Social Networking, 14(4), 213-221.

Jones, P. J. (2006). Resources for promoting online citizenship. Educational Leadership, 63(4), 41.

Kıran Esen, B. \& Gündoğdu, M. (2010). The Relationship between internet addiction, peer pressure and perceived social support among adolescents. The International Journal of Educational Researchers, 2(1), 29-36

Ko, C. H., Yen, J. Y., Yen, C. F., Chen, C. S., Weng, C. C. \& Chen, C. C. (2008). The association between internet addiction and problematic alcohol use in adolescents: The problem behavior model. Cyber Psychology \& Behavior,11(5), 571-576. 
Lamborn, S., Mounts, N., Steinberg, L., \& Dornbusch,S. (1991). Patterns of competence and adjustment among adolescents from authoritative,authoritarian, indulgent, and neglectful homes. Child Development, 62, 1049-1065.

Lin, C. H., Lin, S. L., \& Wu, C. P. (2009). The effects of parental monitoring and leisure boredom on adolescents' Internet addiction. Adolescence, 44(176), 993-1004.

Lim, J., Bae, Y., \& Kim, S. (2004). A learning system for internet addiction prevention. Proceedings of the IEEE International Conference on Advanced Learning Technologies (ICALT'04). http://portal.acm.org/citation.cfm?id=1018423.1020135 adresinden 18.03.2014 tarihinde erişilmiştir.

Mesch, G. S. (2003). The family and the internet: The Israeli case. Social Science Quarterly, 84(4), 1038-1050.

Moazedian, A., Taqavi, S. A., Hosseini Almadani, S. A., Mohammadyfar, M. A. \& Sabetimani, M. (2014). Comparison effectiveness of cognitive - behavioral therapy and metacognitive therapy on improvement of body-image among university students with social phobia. Journal of Life Science Biomedicine, 4(1), 9-14.

Şahin, F. T. \& Kalburan, N. C. (2009). Aile eğitim programları ve etkililiği: Dünyada neler uygulanıyor? Pamukkale Üniversitesi Eğitim Fakültesi Dergisi, 1(25), 1-12.

Valcke, M., Bonte, S., De Wever, B. \& Rots, I. (2010) Internet parenting styles and the impact on Internet use of primary school children. Computers \& Education, 55, 454-464.

Van den Eijnden, R. J. J. M., Spijkerman, R., Vermulst, A. A., Van Rooij, A. J., \& Engels, R. C. M. E. (2010). Compulsive Internet Use Among Adolescents: Bidirectional Parent-Child Relationships. Journal of Abnormal Child Psychology, 38(1), 77-89.

Van Rooij, T. \& van den Eijden, R. (2007). Monitor Internet en Jongeren 2006 en 2007: Ontwikkelingen in internetgebruik en de rol van opvoeding. http://www.ivo.nl/UserFiles/File/Publicaties/2007-10\%20IVO\%20Reeks \%2054\%20\%20Monitor\%20Internet\%20en\%20Jongeren\%202006\%20en\% 202007.pdf adresinden 18 Agustos 2012 tarihinde erişilmiştir.

Wang, R., Bianchi, S. M. \& Raley, S. B. (2005). Teenagers' Internet use and family rules: A research note. Journal of Marriage and Family, 67(5), 1249-1258.

Xiuqin. H., Huimin, Z., Mengchen, L., Jinan, W., Ying, Z. \& Ran, T. (2010). Mental health, personality, and parental rearing styles of adolescents with internet addiction disorder. Cyberpsychology, Behavior, and Social Networking, 13(4), 401-406.

Yang, C. K., Choe, B. M., Baity, M., Lee, J. H. \& Cho, J. S. (2005). SCL 90-R and 16PF profiles of senior high school students with excessive internet use. Canadian Journal of Psychiatry, 50(7), 407-414.

Yen, T. H. (2002). Research on The Relationship between background, behavior of using Internet and psychological characteristics for elementary school students. Unpublished master's thesis. University of Tainan, Tainan, Taiwan.

Yılmaz, A. (2000). Eşler arasındaki uyum ve çocuğun algıladığı anne-baba tutumu ile çocukların, ergenlerin, gençlerin akademik başarıları ve benlik algıları arasındaki ilişkiler. Yayınlanmamış Doktora Tezi, Hacettepe Üniversitesi, Sosyal Bilimler Enstitüsü, Ankara. 
Young, K. S. (2004). Internet addiction: A new clinical phenomenon and its consequences. American Behavioral Scientist, 48(4), 402-415. 


\section{ÖZET}

Aile bireyleri olan anne babaların çocuklara karşı gösterdiği her türlü tutum çocukların ilerleyen dönemlerde gösterecekleri davranışlara temel oluşturacaktır. Teknolojik gelişmelere paralel olarak internetin yaygın olarak kullanılmaya başlanmasıyla birlikte aile bireyleri çocuklarının daha yaygın olarak kullandığı internete karşıda farklı tutumlar göstermekte ve bu tutumlara bağlı olarak da çocukların internet kullanımı konusunda farklı yaklaşımlar sergileyebilmektedir. Alanyazın incelendiğinde farklı aile tutumlarının çocukların internet kullanma davranışlarında etkili olduğu görülmektedir. Bu araştırmanın amacı, ilköğretim öğrencilerinin anne baba tutumları ve internet aile tutumları arasındaki ilişki ile anne baba ve internet aile tutumunun çeşitli değişkenler açısından incelenmesidir.

Araştırmada genel tarama modelindedir. Araştırmada ilköğretim ikinci kademe öğrencilerinin anne baba tutumları ve internet aile tutumları çeşitli değişkenler açısından incelenmiştir. Araştırma 2011-2012 öğretim yılının ikinci döneminde, Sakarya ili merkezinde yer alan bir ilköğretim okulunda öğrenim gören toplam 269 öğrenci ile gerçekleştirilmiştir. Bu öğrencilerin 121'i (\%45) kı, 148'i (\%55) erkektir. Araştırmada ilköğretim ikinci kademe öğrencilerinin aile tutumlarını belirlemek amacıyla Lamborn, Mounts, Steinberg ve Dornbush (1991) tarafından geliştirilen ve Yılmaz (2000) tarafından uyarlanan ölçek kullanılmıştır. Araştırmada kullanılan internet aile tutumu ölçeği van Rooij ve van den Eijden (2007) tarafından geliştirilmiştir. Ölçeğin orijinali Felemenkçedir. Ölçek Valcke, Bonte, De Wever ve Rots (2010) tarafından İngilizceye çevrilerek kullanılmıştır. Ölçek Ayas ve Horzum (2013) tarafından Türkçeye uyarlanmıştır. Araştırmada internet aile tutumları ile diğer değişkenler arasındaki ilişkiye ki kare testi ile bakılmıştır.

Araştırmada anne baba tutumu ihmalkâr olan öğrencilerin internete yönelik aile tutumlarının da daha çok inmalkâr olduğu, Anne-baba tutumu otoriter olan öğrencilerin internete yönelik aile tutumları açısından ihmalkar tutumuna sahip oldukları bulunmuştur. Anne baba tutumu hoşgörülü olan öğrencilerin internete yönelik aile tutumları açısından ağırlıklı olarak demokratik aile tutumuna sahiptir. Bunun yanında anne baba tutumu demokratik olan öğrencilerin internete yönelik aile tutumları açısından daha çok demokratik aile tutumuna sahip oldukları görülmektedir. Anne baba tutumlarının internete yönelik tutumlarında kısmen de olsa benzer ve ilişkili olduğu görülmektedir. İnternet artık hayatımızın her alanına o kadar fazla işgal eder hale geldi ki anne babalarda çok uzun süreler interneti kullanır hale geldiler ve internet konusundaki bilgi ve becerilerini artırdılar. İnternet konusunda gerekli bilgiye sahip olan ailelerde internet konusunda çocuklarına daha olumlu bir tutum sergilemeye başlamış olabilirler. Bundan sonraki çalışmalarda farklı sosyo ekonomik düzeylerden ailelerin hem anne baba tutumu hem de internet aile tutumlarının farklılaşıp farklılaşmadığına yönelik çalışmalar yürütülebilir. Ayrıca bu çalışmada ailelerin her iki tutumu da çocuklar tarafından raporlanmıştır. Bundan sonraki çalışmalarda ailelerin kendi tutumlarını raporlamaları ile çocukların algıladıklarını raporlamaları arasında karşılaştırmalar yapılabilir. 